\title{
Dynamic Effect of Public Expenditure on Oil Producing Economy: An Empirical Evidence from Nigeria
}

\author{
Iyabo A. Olanrele \\ Economics and Business Policy Department, Nigerian Institute of Social and Economic Research (NISER) \\ Nigeria. \\ Email:adeyemiyabo@yahoo.com Tel:08066226531
}

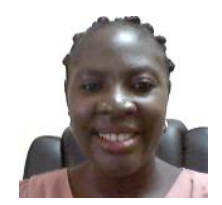

\begin{abstract}
The paper examines the economic growth effect of government expenditure in Nigeria employing annual data from 1970 to 2017. Specifically, the study examines the short- and long-term effect of Federal Government total, recurrent, and capital expenditure on the real Gross Domestic Product (GDP). Different from the existing literature, the paper also shows the extent of oil sector integration, at the sectoral level, by investigating the effect of government expenditure on the agriculture and manufacturing sectors. The analysis was carried out using the Autoregressive Distribute Lag (ARDL) technique. Empirical results show that the aggregate government spending has a positive effect on the real GDP on the short and long-run. Mixed outcomes were realized when the effect of government expenditure on agricultural and manufacturing sector outputs were considered. In the short-run, total government expenditure cause agriculture sector output to decline. The long-run accumulated government spending leads to an increase in the agricultural sector output. The total government expenditure exerts a negative effect on the manufacturing sector output in the short-run. The effect was positive in the long-run. Outcomes from analyzing the differential effect of expenditure types on the real GDP show that capital expenditure had no impact on the real GDP, while government recurrent expenditure had a positive significant impact. Thus, efforts should be geared towards increasing capital spending for commensurate integration of oil benefits in the Nigerian economy.
\end{abstract}

Keywords: Government expenditure, Oil-producing economy, Sectoral output, Recurrent expenditure, Capital expenditure, Nigeria. JEL Classification: E60; E62.

Citation I Jyabo A Olanrele (9090). Dynamic Effect of Public Expenditure on Oil Producing Economy: An Empirical Evidence from Nigeria. Asian Journal of Economics and Empirical Research, $7(1): 64-73$.

History:

Received: 27 November 2019

Revised: 10 January 2020

Accepted: 17 February 2020

Published: 31 March 2020

Licensed: This work is licensed under a Creative Commons

Attribution 3.0 License (cc)

Publisher: Asian Online Journal Publishing Group
Funding: This study received no specific financial support.

Competing Interests: The author declares that there are no conflicts of interests regarding the publication of this paper.

Transparency: The author confirms that the manuscript is an honest, accurate, and transparent account of the study was reported; that no vital features of the study have been omitted; and that any discrepancies from the study as planned have been explained.

Ethical: This study follows all ethical practices during writing.

\section{Contents}

\section{Introduction}

3. Literature Review

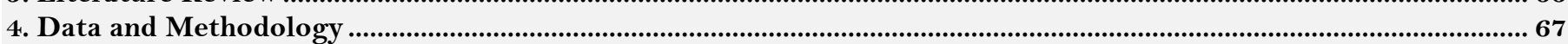

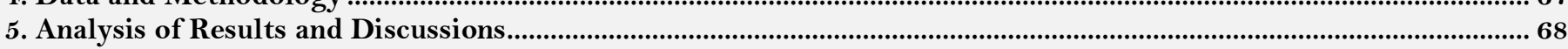

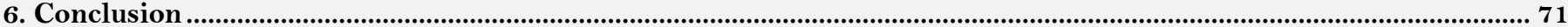

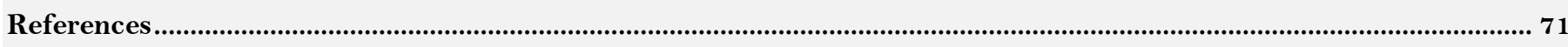

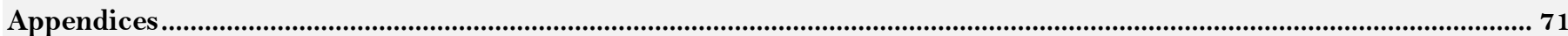




\section{Contribution of this paper to the literature}

The study contributes to the literature by showing the extent to which government expenditure impacts on output at more disaggregated level- agriculture and manufacturing sector outputs. By this, the study was able to capture the extent to which the oil sector integrates with the real sectors of the economy.

\section{Introduction}

In oil producing economies, oil revenue is belief to serve as a main contributor to government budgetary expenditure stirring economic activities. Strong oil dependent nature of these economies, measured by oil export and oil revenue to GDP ratio, supports this claim. While this remains, it is unclear if the performance of these economies, indicated by the real gross domestic product (GDP), is affected by government spending over the years. The underlying assumption is built on a Keynesian notion where public spending is expected to stir economic activities, thereby economic growth.

In a period of 47 years (1970-2017), Nigeria gained about N83,748 billion (72.2\% of total revenue), oil revenue, however, this did not make a meaningful impact on the economy. Federal Government total expenditure increased from No.9 billion in 1970 to about N8, 302 billion in 2017(Central Bank of Nigeria Annual Statistical BulletinCBN, Various issues). The share of recurrent expenditure in total expenditure was about $78 \%$ to $86 \%$ in the review period. While capital expenditure used for financing development projects was just about $28 \%$ and $12 \%$ in the same period. The declining share of capital expenditure is a reflection of the country's bulging population vis-à-vis the size of its civil service. This concern as further shown by the share of government expenditures to GDP, which was between $1.03 \%$ for the recurrent expenditure and $0.14 \%$ for the capital expenditure in 2017 .

While some studies have empirically established the effect of government expenditure on economic growth, outcomes remain inconclusive (Babatunde, 2018; Chude \& Chude, 2013; Ebong, Ogwumike, Udongwo, \& Ayodele, 2016). Departing from this strand of literature, this study examines the relationship between government expenditure and economic growth in Nigeria based on a modified (Barro, 1990) endogenous growth model while applying recent data. Further, I explore the short and long term dynamics of the effect of government expenditure and economic growth. The short-run scenario suits the Keynesian proposition of government short-run intervention. To this effect, the study investigated the subsequent outlined objectives. Firstly, I examine the effect of total public expenditure on aggregate output (real GDP). Secondly, to capture the level of oil sector integration with the other key sectors of the economy, I Investigated the agriculture and manufacturing sector effects of total government expenditure. The selected sectors are the bedrock of the real sector of the Nigerian economy. In the last objective, I analyse the differential effect of public recurrent and capital (development) expenditures on real GDP. The disaggregated analysis is carried out to account for channels of intervention on economic growth.

The study is structured into six sections: section II provides a summary of government expenditure and the Nigerian economy. Section III dwells on the theoretical and empirical review of relevant literature. Section IV presents the methodology and the dataset used in the analysis. Section V presents and discussed the results. The conclusion and some recommendations were provided in section VI.

\section{Government Expenditure and the Nigerian Economy}

Nigeria being an oil dependent economy has, a large chunk of its economic activities dominated by oil revenue. Since the era of global oil boom of the 1970s, the federal government budgetary plans have revolved majorly on crude oil sales proceeds. A clear picture of this is seen in Figure 1, where trend in total government expenditure is closely related to oil revenue. A simple reason for this is because of the dominant share of oil revenue in the total revenue, which is more than 50 per cent in the entire period of 1970 to 2017 Table 1.

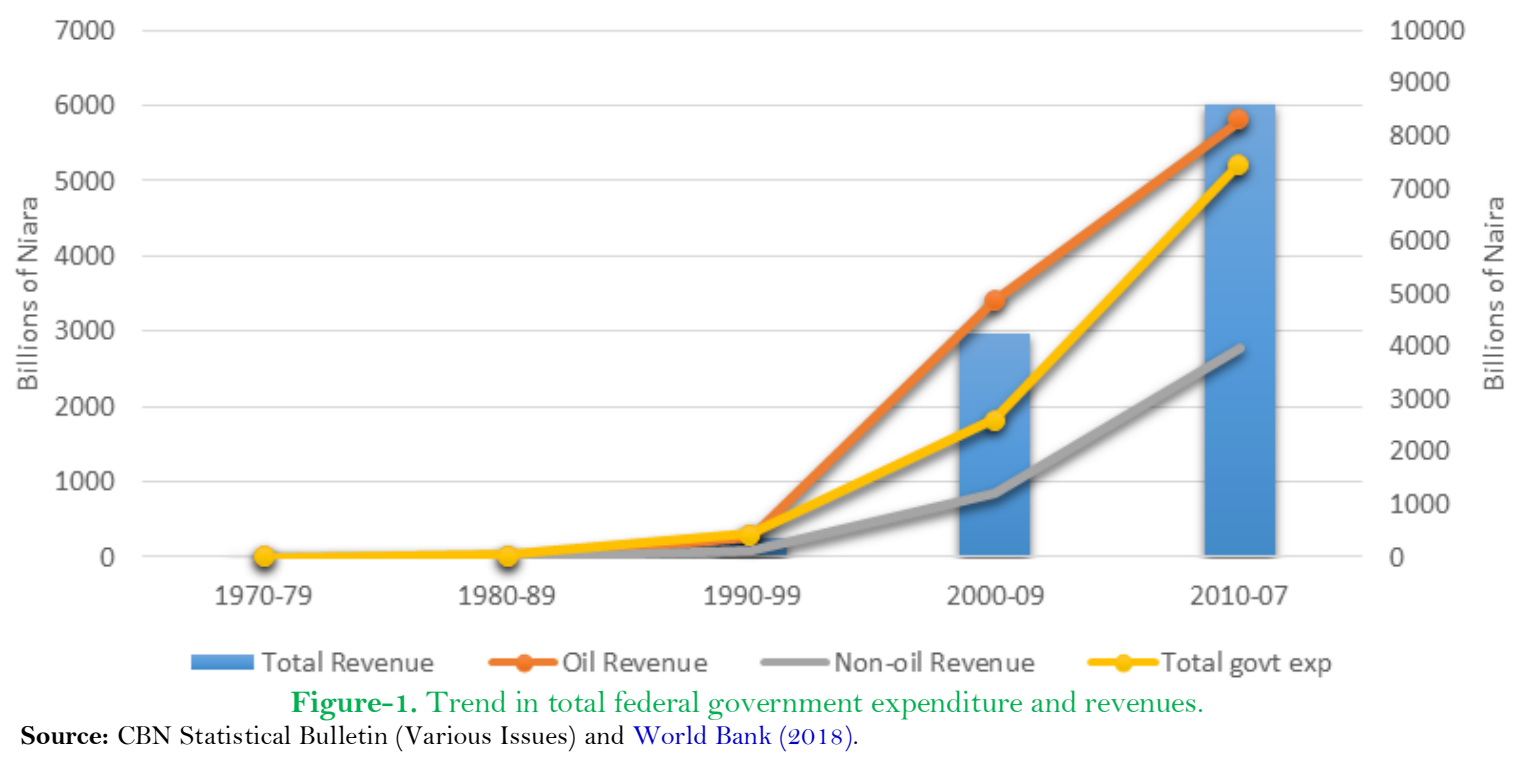

Total Federal Government expenditure in Nigeria, which comprise of recurrent and capital expenditures, has grown significantly over the years. Total Federal Government expenditure in the period 1970-1979 increases from $\mathrm{N} 4.8$ billion to $\mathrm{N} 8601.7$ billion in 2010-2017, suggesting a gradual expansion in government activities. The share of capital expenditure, which was about $57 \%$ in the period $1970-79$, declined drastically, giving way to recurrent expenditure in the subsequent period. By 2010-07, it has decreased to $16.8 \%$. The burden of recurrent expenditure became huge as a result of the over-bloated size of the country's civil service that has continue to constraint 
development expenditure. Although government activities are on the increase, the size, measured by total Federal Government expenditure to real GDP, is below $1 \%$ over the past four decades Table 1.

Table-1. Summary of fiscal aggregates (annual average).

\begin{tabular}{|c|c|c|c|c|c|}
\hline & 1970-79 & 1980-89 & 1990-99 & 2000-09 & 2010-07 \\
\hline \multicolumn{6}{|l|}{ Federal Government Revenue } \\
\hline Total Revenue (Billions of Naira & 4.8 & 19.6 & 376.3 & 4231.7 & 8601.7 \\
\hline Oil Revenue (\% of Total) & 73.5 & 72.0 & 75.5 & 80.8 & 67.6 \\
\hline Non-oil Revenue (\% of Total) & 26.5 & 27.9 & 24.5 & 19.2 & 32.4 \\
\hline \multicolumn{6}{|l|}{ Federal Government Expenditure } \\
\hline Total Expenditure ( Billions of Naira) & 4.3 & 17.9 & 302.1 & 1829.4 & 5217.1 \\
\hline Recurrent Expenditure (\% of Total) & 50.4 & 57.0 & 46.1 & 66.2 & 80.5 \\
\hline Capital Expenditure (\% of Total) & 57.2 & 42.4 & 53.9 & 30.3 & 16.8 \\
\hline Total Expenditure (\% of Real GDP) & 0.00 & 0.01 & 0.13 & 0.49 & 0.82 \\
\hline
\end{tabular}

Increase in the size of Nigeria's economy was not directly linked to total Federal Government expenditure Figure 2. Although moving in the same direction, total Federal Government expenditure saw significant improvement from 1999, a period that coincides with the beginning of Nigeria's civil regime. For instance, total expenditure that was about N487 billion in 1998 suddenly surged to about N948 in 1999, which is about 95\% increase between the two-year period. Hitherto, the military regime was the mainstay of the country, with its attendant effect on government activities. Beyond this, recurrent expenditure drives the overall movement in total expenditure compared to the capital expenditure that has no clear-cut relationship with the size of Nigeria's economy measured by the real GDP Figure 3.
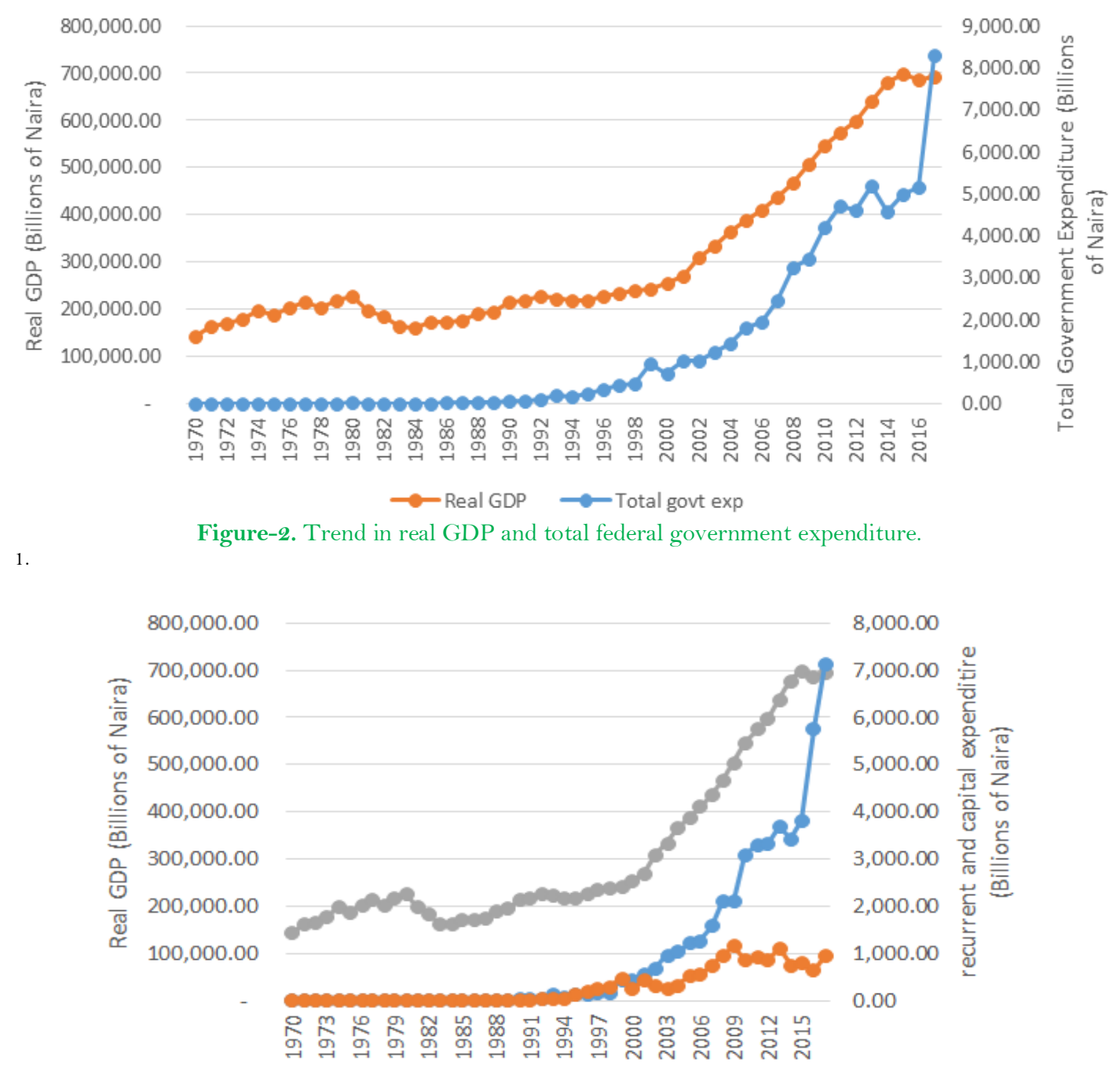

$\longrightarrow$ Real GDP $\longrightarrow$ recurrent exp $\longrightarrow$ capital exp

Figure-3. Trend in real GDP and government expenditures.

\section{Literature Review}

\subsection{Theory of Government Expenditure}

The Wagner's law of increasing state activities hypothesized that as the state develops, the real income increases, and as such, the share of public expenditure may increase in the long-run (Magazzino, Giolli, \& Mele, 2015; Wijeweera \& Garis, 2009). Thus, the period of development is accompanied by large size government expenditure. The assumption is that: first, when the economy grows, development would occur and as such, the role of public sector diminished to accommodate the private sector. Second, as the economy evolves, the need for basic infrastructures, such as education and health infrastructures, would lead to a rise in real income.

In a contrary opinion, Wiseman and Peacock stated that public expenditure moves in a cyclical manner and not in a smooth pattern. The study by Taiwo and Abayomi (2011) and Magazzino et al. (2015) explained that as the size of the economy increases, public expenditure would show a gradual upward trend. However, periodic distortions tend to alter the smooth path of public expenditure. The distortions usually occur in periods of war, 
social unrest, natural disaster etc. As such, it would become imperative to increase public spending by raising taxation. The situation is known as the Peacock-Wiseman displacement effect.

According to Keynes, public expenditure is an exogenous phenomenon that can stimulate economic growth (Gukat \& Ogboru, 2017). By this, it is expected that government stimulates economic activities, thus, increasing aggregate demand. As such, public expenditure stabilizes the economy in the short-run. However, persistent increase in government expenditure has implication for increasing the general price level, thus, causing unemployment.

\subsection{Public Expenditure and the Economy: An Empirical Review}

At the aggregate and disaggregate level, several studies have examined the issue of public expenditureeconomic growth nexus. Findings, however, remain inconclusive. The subsequent discussion presents some of the studies that conclude for the positive effects of government expenditure, followed by the summary of the studies that found no impact on the Nigerian economy.

A study by Olayungbo and Olayemi (2018) examined the relationships among non-oil revenue, government spending, and economic growth. They used data from 1981 to 2015 based on an Error Correction Model, impulse response and Granger causality test. The results of the short run and long run indicated that government spending exerts a negative effect on economic growth. Okolo, Edeme, and Emmanuel (2018) examined the relationship between capital expenditure and infrastructural development in Nigeria using data for the period 1970 to 2017. The estimation was carried out using an Autoregressive distributed lag (ARDL) model. Findings from the study reveals that capital expenditure has a potential to engender a positive impact on infrastructural development in the long-run if not hindered by external debt.

Gukat and Ogboru (2017) investigates the effects of government expenditure on the Nigerian economic growth. An Ordinary Least Square technique and an Error Correction Model were employed with data from 1981 to 2016. Their result shows that government expenditure has no effect on economic growth. Likewise, a study by Ajayi and Aluko (2016) reveals that government expenditure has no effect on economic growth.

A disaggregated effect of government expenditure on economic growth was investigated by Ogundipe and Oluwatobi (2013). The analysis was based on the Johansen technique for the period of 1970-2009. The study revealed a short-run negative effect of capital expenditure impacted negatively on economic growth.

The study by Chude and Chude (2013) was among the strand of literature that show the positive effect of government expenditure on economic growth. The study investigated the effect of public education expenditure on economic growth in Nigeria for the period 1977 to 2012. An Error Correction Model (ECM) was employed. Their findings established a long-run positive relationship between government education expenditure and economic growth. Using a Granger causality test and the Johansen cointegration technique, a study by Okoro (2013) shows that a long-run relationship between government spending and economic growth in Nigeria exist.

Several other studies came out with a mixed evidence. For example, Dikeogu, Ohale, and Otto (2016) examined the impact of public expenditure on economic growth in Nigeria from 1970 to 2013. The study adopted the econometric technique of Ordinary Least Squares (OLS) and Error Correct Mechanism (ECM). The findings reveal that aggregate government expenditure do not impact significantly on economic growth, while disaggregate government expenditure exerts a significant impact on economic growth. Ebong et al. (2016) assesses the impact of government capital expenditure on economic growth in Nigeria using data for 1970 to 2012. The study made use of Ordinary Least Square regression technique. The results show that Capital expenditures on Agriculture have no significant influence on growth both in the long and short runs. Short-run and long-run impacts on growth of capital expenditures were positive.

Nworji, Okwu, Obiwuru, and Nworji (2012) examined the effect of public expenditure on economic growth in Nigeria for the period 1970 - 2009. The study made used of the OLS regression technique. Empirical findings showed that capital and recurrent expenditure on economic services had insignificant negative effect on economic growth. However, capital and recurrent expenditures on social and community services and recurrent expenditure on transfers had significant positive effect on economic growth.

\section{Data and Methodology}

\subsection{Data}

The data type employed in this study is secondary in nature, spanning the period of 1970-2017. This period, in the history of Nigeria's development, covers the era of oil boom and oil decline. The era of oil boom is associated with increasing oil revenue, which is expected to pass-through government expenditure and its overall size in economic activities. In the four specified models, nine (9) variables were used and sourced from various national and international data base.

Real GDP is the aggregate output, computed as the sum of gross value-added by all resident producers in Nigeria measured in constant local currency (WDI, 2018). Agricultural and manufacturing sector GDP is the monetary value of goods and services produced in the respective sectors (CBN, various Issues). Total government expenditure is an outflow of resources from government to other sectors of the economy whether requited or unrequited and is divided into recurrent expenditure (payments for salaries and overheads) and capital expenditure (payments for non-financial assets) (CBN, Various Issues). The inflation rate is designed to measure the rate of increase in aprice index and is a percentage rate of change in consumer price level over time (CBN, Various Issues). The interest rate employed in this study is the prime lending rate, which is the lending rate used in providing loan and advances. It is computed from monthly interest rate returns (CBN, Various Issues). Domestic credit to private sector refers to financial resources provided to the private sector by financial corporations, such as through loans, purchases of non-equity securities, and trade credits and other accounts receivable, that establish a claim for repayment (WDI, 2018). In this study the private sector credit is given as a share of GDP. 


\subsection{Methodology}

The basic framework employed in this study is the endogenous growth model developed by Barro (1990). The framework incorporates public sector into a simple economic growth model to capture the empirical predictions in the size of government and economic growth nexus. In this study, the framework is modified to capture some peculiarities of the Nigerian economy, hence a simple production model with the interaction of government expenditure is specified as:

$$
\text { OUTPUT }_{t}=f\left(\text { GEXP }_{t}, \text { INFLATION }_{t}, \text { PCRED }_{t}, I N T R_{t}\right)
$$

The estimable form of equation (1) is further expressed as;

$\emptyset_{1}, \emptyset_{3}>0 ; \emptyset_{2}, \emptyset_{4}<0$,

$$
\text { OUTPUT }_{t}=\emptyset_{0}+\emptyset_{1} G E X P_{t}+\emptyset_{2} \text { INFLATION }_{t}+\emptyset_{3} P C R E D_{t}+\emptyset_{4} I N T R_{t}+\varepsilon_{t}
$$

In Equation 1, real Gross Domestic product (RGDP) is a measure of output, which may be aggregate output (RGDP), agricultural sector output (GDPAgric), or manufacturing sector output (GDPman). Government expenditure $(G E X P)$ is an indicator of either total federal government expenditure, capital (CAPEX) or recurrent expenditure (REPEX). While other control parameters such as inflation (INFLATION), credit to private sector (PCRED), and interest rate (INTR) are allow to serve as control variables predicating the behaviour of the aggregate output in Nigeria (Arewa \& Nwakahma, 2013; Austin \& Ogbole, 2014).

In ascertaining the short and long-run dynamic behaviour of the relationships, an Autoregressive Distributed Lag (ARDL) model is employed. Although suitable for small and large sample size, the short-run scenario suits Keynes proposition of government short-run intervention.

In analyzing the ARDL model, the long-run cointegration must be established. When cointegration is established, the short and long-run model will be estimated based on Equations 3 and 4 specified below. Further, in analyzing the model, an appropriate lag length has to be selected, which is usually based on the least lag length selection criterion.

The conditional ARDL $(p, q 1 \ldots q 4)$ and $(p, q 1)$, the long-run model for OUTPUT indicator was estimated based on the specification in Equation 3.

$$
\begin{aligned}
& \begin{array}{c}
\operatorname{lnOUTPUT}_{t}= \\
\beta_{0}+\sum_{i=1}^{p} \beta_{1} \operatorname{lnOUTPUT}_{t-1}+\sum_{i=0}^{q 1} \beta_{2} \operatorname{lnGEXP}_{t-1}+\sum_{i=0}^{q 2} \beta_{3} \operatorname{lnINFLATION}_{t-1}+\sum_{i=0}^{q 3} \beta_{4} \ln \text { IRED }_{t-1}+
\end{array} \\
& \sum_{i=0}^{q 4} \beta_{5} \operatorname{lnINTR}_{t-1} \mu_{t}
\end{aligned}
$$

The ECM representation of the model is given by:

$$
\begin{aligned}
& \Delta \operatorname{lnOUTPUT}_{t}= \\
& \beta_{0}+\sum_{i=1}^{p} \beta_{1} \Delta \text { OUTPUT }_{t-1}+\sum_{i=0}^{q 1} \beta_{2} \Delta \ln G E X P_{t-1}+\sum_{i=0}^{q 2} \beta_{3} \Delta \operatorname{lnINFLATION}+\sum_{i=0}^{q 3} \beta_{4} \Delta \ln P C R E D_{t-1}+ \\
& \sum_{i=0}^{q 4} \beta_{5} \operatorname{lnIINTR}_{t-1}+\rho E C M_{t-1}+\mu_{t}
\end{aligned}
$$

The speed of adjustment is denoted $\rho$ in Equation 4, which is the error correction mechanism. Its coefficient is expected to turn out negative and significant for confirmation of a short-run relationship.

The remaining part of the section highlights the process of the model estimation technique outlined within the ARDL technique. A perquisite in a time series analysis is to check the stationarity of the data, so as to avoid making a misleading policy decision. As such, the study checked for the unit root properties of the selected variables in the model setup based on the Augmented Dickey Fuller (ADF) and Philips Perron (PP) tests. The following step dwells on establishing the long-run cointegration relationship, and then the short-run and long-run estimates.

\section{Analysis of Results and Discussions}

\subsection{Unit Root Test}

The ARDL bound test requires that the order of integration of all variables do not exceed I(1), as ARDL bound test is hinged on the basic assumption that the series are either $\mathrm{I}(0), \mathrm{I}(1)$ or a mixture of both (Ouattara, 2004; Pesaran, Shin, \& Smith, 2001). Using the Augmented Dickey-Fuller (ADF) and Phillips Perron (PP) unit root tests, the order of integration of the variables are $\mathrm{I}(1)$ as expressed in Table 2. Having established this, we proceed to testing for the long-run cointegrating relationship in the models.

Table-2. Unit root test result.

\begin{tabular}{l|c|c|c|c|c|c}
\hline & \multicolumn{7}{|l|}{ Augmented Dickey Fuller } & & \multicolumn{2}{l|}{ Phillips Perron } & \\
\hline Variable & Intercept & Intercept and Trend & Remarks & Intercept & Intercept and Trend & Remarks \\
\hline TOEXP & -7.627 & -7.770 & $\mathrm{I}(1)$ & -7.591 & -7.733 & $\mathrm{I}(1)$ \\
\hline REPEX & -8.226 & -8.147 & $\mathrm{I}(1)$ & -8.504 & -8.437 & $\mathrm{I}(1)$ \\
\hline CAPEX & -7.044 & -7.667 & $\mathrm{I}(1)$ & -7.120 & -7.607 & $\mathrm{I}(1)$ \\
\hline INFLATION & -6.989 & -6.933 & $\mathrm{I}(1)$ & -14.298 & -14.395 & $\mathrm{I}(1)$ \\
\hline INTR & -7.714 & -7.620 & $\mathrm{I}(1)$ & -9.664 & -9.535 & $\mathrm{I}(1)$ \\
\hline RGDPagric & -5.810 & -5.708 & $\mathrm{I}(1)$ & -5.804 & -5.739 & $\mathrm{I}(1)$ \\
\hline RGDPman & -4.900 & -5.349 & $1(1)$ & -6.777 & -6.788 & $\mathrm{I}(1)$ \\
\hline RGDP & -5.109 & -5.381 & $\mathrm{I}(1)$ & -5.266 & -5.435 & $\mathrm{I}(1)$ \\
\hline PCRED & -4.289 & -4.102 & $\mathrm{I}(1)$ & -4.881 & -4.217 & $\mathrm{I}(1)$ \\
\hline
\end{tabular}

\subsection{Bound Test Cointegration}

The bound test results presented in Table 3 shows the long-run cointegration relationship in the four (4) models empirically analyzed in this study. Cointegrating relationship is determined by comparing the computed FStatistic, which captures the statistical significance of the model with the lower and upper bound critical values provided by Narayan (2004). The null hypothesis suggests that all slope coefficients are equal to zero, where the FStatistic falls within the upper and lower bound critical values. The calculated F-statistics of RGDP model of 4.269 is higher than the upper critical value for $\mathrm{I}(1)$ bound at 5 per cent. However, RGDPagric model was found to be 
inconclusive since the calculated F-statistics (3.224) lied between the critical value for I(O) and I(1) bounds at 10 per cent. This suggests that both the long and short-run models can be considered. The calculated F-statistics of RGDPman and RGDP* models of 6.024 and 4.269 is higher than the upper critical value for $\mathrm{I}(1)$ bound at 1 and 5 per cent respectively. Therefore, we reject the null hypothesis and conclude for a cointegrating relationship.

\begin{tabular}{|c|c|c|c|}
\hline Model & $\mathbf{K}$ & F-stat & Outcome \\
\hline$R G D P=f(T O E X P, I N F L A T I O N, I N T R, P C R E D)$ & 3 & 4.821 & Cointegrated \\
\hline RGDPagric $=f(T O E X P, I N F L A T I O N, I N T R, P C R E D)$ & 3 & 3.224 & Cointegrated \\
\hline RGDPman $=f(T O E X P, I N F L A T I O N, I N T R$, PCRED $)$ & 3 & 6.024 & Cointegrated \\
\hline$R G D P^{*}=(R E P E X, C A P E X, I N F L A T I O N, I N T R, P C R E D)$ & 4 & 4.269 & Cointegrated \\
\hline
\end{tabular}

\subsection{Estimated Results}

The various estimations carried out in the study are presented in Table 4 to 7 . Table 4 shows the result on real GDP and total expenditure. As expected, total government expenditure (TOPEX) has a positive impact on real GDP (RGDP) on the short and long-run. Both scenarios are significant at $1 \%$. Other control variables came out with the expected sign on the short and long-run. The significance of the relationship was consistent for inflation rate (INFLATION) and the private sector credit (PCRED) in both scenarios.

Table-4. Estimated short and long-run coefficients for real aggregate output model.

\begin{tabular}{|c|c|c|c|c|}
\hline \multicolumn{5}{|c|}{$\begin{array}{l}\text { Dependent Variable: RGDP } \\
\text { Selected Model: (4,O,O,5 } \\
\text { Criterion: Adjusted R }{ }^{2} \\
\end{array}$} \\
\hline \multicolumn{5}{|c|}{ Short-run Cointegrating Form } \\
\hline Variable & Coefficient & Std. Error & t-Statistic & Prob. \\
\hline$D(R G D P(-1))$ & 0.127 & 0.144 & 0.882 & 0.385 \\
\hline $\mathrm{D}(\mathrm{TOPEX})$ & 0.025 & 0.009 & 2.931 & 0.007 \\
\hline $\bar{D}(I N T R)$ & 0.001 & 0.002 & 0.812 & 0.423 \\
\hline$D(I N F L A T I O N)$ & -0.002 & 0.001 & $-2,428$ & 0.022 \\
\hline $\mathrm{D}($ PCRED $)$ & 0.005 & 0.003 & 1.955 & 0.060 \\
\hline CointEq(-1) & -0.185 & 0.045 & -4.115 & 0.000 \\
\hline \multirow{2}{*}{\multicolumn{5}{|c|}{$\begin{array}{l}\mathrm{ECM}= \\
\text { Long-run Cointegrating Form }\end{array}$}} \\
\hline & & & & \\
\hline Variable & Coefficient & Std. Error & t-Statistic & Prob. \\
\hline TOEXP & 0.135 & 0.034 & 3.936 & 0.001 \\
\hline$I N T R$ & 0.008 & 0.010 & 0.795 & 0.433 \\
\hline INFLATION & -0.014 & 0.005 & -3.145 & 0.004 \\
\hline PCRED & 0.029 & 0.013 & 2.189 & 0.037 \\
\hline$C$ & 11.726 & 0.168 & 69.999 & 0.000 \\
\hline
\end{tabular}

The output indicator, real GDP (RGDP) was disaggregated to capture the possibility of the integration of the oil sector revenue through total government expenditure in enhancing sectoral inclusiveness. As such, Tables 5 and 6 show the impact of total government expenditure (TOPEX) on agricultural and the manufacturing sector respectively. The short-run impact of total government expenditure was negative and insignificant on agriculture output. Specifically, a $1 \%$ increase in total government expenditure dampens agriculture sector performance by about $0.2 \%$. This could be as a result of non-integration of oil revenue through government expenditure on the real sector of the economy. With accumulated government spending, total government expenditure engenders agricultural output growth to about $0.2 \%$ on the long-run at a $5 \%$ level of significance. Only inflation rate (INFLATION) turns out with an expected significant sign on the long-run. Other variables were perverse in sign and insignificance.

Table-5. Estimated short and long-run coefficients for agricultural output model.

Dependent Variable: RGDPagric

Selected Model: $(3,3,0,4)$

Criterion: Adjusted $\mathrm{R}^{2}$

Short-run Cointegrating Form

\begin{tabular}{l|c|c|c|c}
\hline Variable & Coefficient & Std. Error & t-Statistic & Prob. \\
\hline$D($ RGDPagric $(-1))$ & 0.268 & 0.179 & 1.499 & 0.144 \\
\hline$D(I N F L A T I O N)$ & -0.002 & 0.003 & -0.615 & 0.543 \\
\hline$D(I N T R)$ & -0.006 & 0.008 & -0.741 & 0.465 \\
\hline$D($ TOEXP(-1) & -0.191 & 0.203 & -0.938 & 0.356 \\
\hline$D($ PCRED $)$ & 0.012 & 0.013 & 0.875 & 0.389 \\
\hline CointEq(-1) & -0.344 & 0.114 & -3.025 & 0.005 \\
\hline Long-run Cointegrating Form & \multicolumn{3}{|c}{ Prob. } \\
\hline Variable & Coefficient & Std. Error & t-Statistic & 0.083 \\
\hline INFLATION & -0.021 & 0.012 & -1.795 & 0.459 \\
\hline$I N T R$ & -0.017 & 0.023 & -0.751 & 0.034 \\
\hline TOEXP & 0.174 & 0.078 & 2.227 & 0.328 \\
\hline PCRED & 0.034 & 0.034 & 0.995 & 0.000
\end{tabular}

Note: RGDPagric is real gross domestic product of the agricultural sector, TOPEX is total Federal government expenditure, INTR is nominal interest rate, INFLATION is the consumer price inflation rate, and PCRED is credit to private sector. 
The total government expenditure (TOPEX) has a negative and significant effect on the manufacturing sector output (RDGPman) on the short-run, Table 6. The long-run scenario, though positive, is not significant. Obvious of the infrastructural dearth in the country, public expenditure overtime has not been productive considering the short-run negative impact and the weak long-run relationship on the manufacturing sector output. Hence, with the magnitude of oil revenue realized in the country, total government expenditure did not impact on the manufacturing sector output. In the short and long-run, all other variables in the model came out with the expected signs, except for the interest rate (INTR), which is positive on the long-run. Their levels of significance is presented in the result.

Table-6. Estimated short and long-run coefficients for manufacturing output model.

\begin{tabular}{|c|c|c|c|c|}
\hline \multicolumn{5}{|c|}{$\begin{array}{l}\text { Dependent Variable: RGDPman } \\
\text { Selected Model: }(4,3,1,1) \\
\text { Criterion: AIC } \\
\text { FIXED REGRESSOR: }\end{array}$} \\
\hline \multicolumn{5}{|c|}{ Short-run Cointegrating Form } \\
\hline Variable & Coefficient & Std. Error & t-Statistic & Prob. \\
\hline$D(R G D P \operatorname{man}(-2))$ & 0.529 & 0.162 & 3.273 & 0.003 \\
\hline $\mathrm{D}(\mathrm{TOPEX}(-1)$ & -0.331 & 0.164 & -2.019 & 0.053 \\
\hline $\mathrm{D}(\mathrm{INTR})$ & -0.001 & 0.008 & -0.082 & 0.935 \\
\hline$D(I N F L A T I O N)$ & -0.003 & 0.002 & -1.310 & 0.200 \\
\hline $\mathrm{D}($ PCRED $)$ & 0.023 & 0.011 & 2.129 & 0.042 \\
\hline CointEq(-1) & -0.465 & 0.101 & -4.603 & 0.000 \\
\hline \multicolumn{5}{|c|}{ Long-run Cointegrating Form } \\
\hline Variable & Coefficient & Std. Error & t-Statistic & Prob. \\
\hline TOEXP & 0.013 & 0.055 & 0.230 & 0.820 \\
\hline$I N T R$ & 0.029 & 0.017 & 1.669 & 0.106 \\
\hline INFLATION & -0.002 & 0.005 & -0.472 & 0.640 \\
\hline PCRED & 0.049 & 0.022 & 2.223 & 0.034 \\
\hline$C$ & 6.883 & 0.246 & 27.982 & 0.000 \\
\hline
\end{tabular}

Note: RGDP is real gross domestic product of the manufacturing sector, TOPEX is total Federal government expenditure, INTR is nominal interest rate, INFLATION is the consumer price inflation rate, and PCRED is credit to private sector.

In considering the differential effects of expenditure types on real GDP (RGDP), I consider the effect of recurrent and capital expenditure on RGDP, Table 7. The results show that capital expenditure, both on the short and long-run, makes no impact on RGDP. Unlike the short-run, the finding is significant on the long-run. An increase in capital expenditure rather worsens the aggregate output growth. Distinctly, the short and long-run effect of recurrent expenditure was positive on the real GDP and only significant, at $1 \%$, on the long-run. It is important to note that: first, the effect of the recurrent expenditure in total government expenditure explains the plausible observed impact on the real GDP growth second, the results obtained reaffirm the trend analysis presented in Figure 3 (section 2).

Across board, the short-run error correction mechanism (ECM), performed to expectation, in term of the signs and significance. Implying that the short-run models quickly revert to the long-run equilibrium value.

Table-7. Estimated short and long-run coefficients of aggregate output model with disaggregated expenditure.

Dependent Variable: RGDP

Selected Model: $(4,1,1,1,1)$

Criterion: Adjusted R ${ }^{2}$

Short-run Cointegrating Form

\begin{tabular}{l|c|c|c|c}
\hline Variable & Coefficient & Std. Error & t-Statistic & Prob. \\
\hline$D($ RGDP $(-1))$ & 0.188 & 0.143 & 1.312 & 0.200 \\
\hline$D($ CAPEX $)$ & -0.020 & 0.025 & -0.817 & 0.420 \\
\hline$D($ REPEX $)$ & 0.024 & 0.035 & 0.686 & 0.498 \\
\hline$D(I N T R)$ & 0.001 & 0.002 & 0.660 & 0.514 \\
\hline$D(I N F L A T I O N)$ & -0.002 & 0.001 & $-3.5 I 8$ & 0.001 \\
\hline$D(P C R E D)$ & 0.006 & 0.003 & 2.133 & 0.000 \\
\hline CointEq(-1) & -0.213 & 0.049 & -4.312 & Prob. \\
\hline Long-run Cointegrating Form & Coefficient & Std. Error & t-Statistic & 0.001 \\
\hline Variable & -0.268 & 0.076 & -3.542 & 0.000 \\
\hline$C A P E X$ & 0.357 & 0.070 & 5.110 & 0.496 \\
\hline REPEX & -0.007 & 0.010 & -0.690 & 0.256 \\
\hline$I N T R$ & -0.003 & 0.003 & -1.158 & 0.021 \\
\hline INFLATION & 0.029 & 0.012 & 2.443 & 0.000 \\
\hline$C$ PCRED & 11.956 & 0.148 & 80.569 & C \\
\hline
\end{tabular}

Note: RGDP is real gross domestic product, REPEX is total Federal government recurrent expenditure, CAPEX is total Federal government capital expenditure, INTR is nominal interest rate, INFLATION is the consumer price inflation rate, and PCRED is credit to private sector.

In ascertaining the credibility of the adopted models, especially for policy inferences, the LM test for serial correlation was employed. The Cumulative Sum of Recursive Residuals (CUSUM) stability condition of the error correction for each of the model was also tested. These are reported in appendix 1 and 2 . The test for serial correlation was conducted based on the null hypothesis that the residuals are serially uncorrelated. The F-Statistic $p$-values, which are insignificant, indicate the acceptance of this null (Appendix 1). Thus, the conclusion that the 
residuals are serially uncorrelated. The stability condition of the error correction models, which was tested based on Cumulative Sum of Recursive Residuals (CUSUM), show that all plots fall within the critical bands, hence, the four (4) short-run models are structurally stable Appendix 2.

\section{Conclusion}

Oil revenue is belief to serve as a major source of public expenditure stirring economic activities in oilproducing countries. Hence, this study examines the dynamic effects of government expenditure on economic growth in Nigeria, using data from 1970 to 2017. The short and long-run scenarios were analyzed based on the ARDL approach. Specifically, the study examines the effects of total government expenditure on the real GDP. Distinct from existing literature, I show the level of oil sector integration on the key sectors of the economy by investigated the agriculture and manufacturing sector effects of total government expenditure. The last objective analyses the differential effects of government recurrent and capital (development) expenditure on the real GDP.

Results of the first objective showed that total government expenditure has a positive impact on the real GDP in the short and long-run. Mixed outcomes were realized when the effect of government expenditure on agricultural and manufacturing sector outputs was considered. In the short-run, total government expenditure decreases agriculture output. Long-run accumulated government spending increases the agricultural output growth. On the manufacturing sector output, the total government expenditure exerts a negative effect in the short-run. The long-run scenario, though positive, is not significant. Results from analyzing the differential effects of expenditure types on real GDP showed that capital expenditure, both in the short and long-run, makes no impact on the real GDP. However, the recurrent expenditure has a positive significant effect on the real GDP, both in the short and long-run. Suggesting that the effect of the recurrent expenditure in total government expenditure explains the plausible observed impact on the real GDP growth. From the empirical findings, the huge magnitude of oil revenue realized in the country has not increase the impact of government expenditure, especially the capital spending that spurs productive activities, and by implication economic growth. This suggest that efforts should be geared towards increasing capital spending for commensurate integration of oil benefits into the major sectors of the economy and the economy at large.

Further research should explore the relationship between government expenditure and economic growth across the major oil producing countries in Africa. This will avail the opportunity of establishing the extent to which the benefits from oil revenue have enhance real sector development across African oil-producing economies. .

\section{References}

Ajayi, M. A., \& Aluko, O. A. (2016). The causality between government expenditure and economic growth in Nigeria: A toda-yamamoto approach. Journal of Economics छ Business Research, 22(2), 77-89.

Arewa, A., \& Nwakahma, P. C. (2013). Macroeconomic variables and the dynamic effect of public expenditure: Long-term trend analysis in Nigeria. Journal of Knowledge Management, Economics and Information Technology, 3(6), 1-2.

Austin, M. A., \& Ogbole, O. F. (2014). Public sector spending and macroeconomic variables in Nigeria. European Journal of Business and Management, 6(18), 232-243.

Babatunde, S. A. (2018). Government spending on infrastructure and economic growth in Nigeria. Economic research-Ekonomska istraživanja, 31(1), 997-1014.Available at: https://doi.org/10.1080/1331677x.2018.1436453.

Barro, R. J. (1990). Government spending in a simple model of endogeneous growth. Journal of Political Economy, 98(5, Part 2), S103S125.Available at: https://doi.org/10.1086/261726.

Chude, N. P., \& Chude, D. I. (2013). Impact of government expenditure on economic growth in Nigeria. International Journal of Business and Management Review, 1(4), 64-71.

Dikeogu, C. C., Ohale, L., \& Otto, G. (2016). Public expenditure and economic growth in Nigeria. International Journal of Advanced Academic Research | Social \& Management Sciences, 2(12), 23-40.

Ebong, F., Ogwumike, F., Udongwo, U., \& Ayodele, O. (2016). Impact of government expenditure on economic growth in Nigeria: A disaggregated analysis. Asian Journal of Economics and Empirical Research, 3(1), 113-121.

Gukat, B. T., \& Ogboru, I. (2017). An empirical analysis of government expenditure and economic growth in Nigeria. Journal of Economics and Development Studies, 5(4), 122-134.

Magazzino, C., Giolli, L., \& Mele, M. (2015). Wagner's law and Peacock and Wiseman's displacement effect in European Union countries: A panel data study. International Journal of Economics and Financial Issues, 5(3), 812-819.

Narayan, P. K. (2004). Fiji's tourism exports: an ARDL model. Tourism Economics, 10(2), 193-206.Available at: https://doi.or/10.5367/000000004323142425.

Nworji, I. D., Okwu, A. T., Obiwuru, T., \& Nworji, L. O. (2012). Effects of public expenditure on economic growth in Nigeria: A disaggregated time series analysis. International Journal of Management Sciences and Business Research, 1(7), 1-15.

Ogundipe, A., \& Oluwatobi, J. (2013). Government spending and economic growth in Nigeria: Evidence from disaggregated analysis. Journal of Business Management and Applied Economics, 2(4), 1-10.

Okolo, C. V., Edeme, R. K., \& Emmanuel, C. (2018). Economic analysis of capital expenditure and infrastructural development in Nigeria. Journal of Infrastructure Development, 1O(1-2), 52-62.Available at: https://doi.org/10.1177/0974930618809173.

Okoro, A. S. (2013). Government spending and economic growth in Nigeria (1980-2011). Global Journal of Management and Business Research Economics and Commerce, 13(5), 35-42.

Olayungbo, D., \& Olayemi, O. (2018). Dynamic relationships among non-oil revenue, government spending and economic growth in an oil producing country: Evidence from Nigeria. Future Business Journal, 4(2), 246-260.Available at: https://doi.org/10.1016/j.fbj.2018.07.002. Ouattara, B. (2004). Modelling the long run determinants of private investment in Senegal. The School of Economics Discussion Paper
Series 0413, Economics, The Univesrity of Manchester.

Pesaran, M. H., Shin, Y., \& Smith, R. J. (2001). Bounds testing approaches to the analysis of level relationships. Journal of Applied Econometrics, 16(3), 289-326.Available at: https://doi.org/10.1002/jae.616.

Taiwo, M., \& Abayomi, T. (2011). Government expenditure and economic development: Empirical eveidence from Nigeria. European Journal of Business Management, 3(9), 19-28.

Wijeweera, A., \& Garis, T. (2009). Wagner's law and social welfare: The case of the Kingdom of Saudi Arabia. Applied Econometrics and International Development, 9(2), 199-209.

World Bank. (2018). World development indicators. Retrieved from: https://data.worldbank.org/country/nigeria.

\section{Appendices}

The results of tests of serial correlation for the various models adopted in this study are presented in Appendix 1. The F-Statistic $p$-values, which are insignificant, indicate the acceptance of the null hypothesis of no serial correlation in the estimated models. 


\begin{tabular}{|c|c|c|}
\hline Model & Prob. Chi-square & F-Statistic $p$-value \\
\hline$R G D P=f(T O E X P, I N F L A T I O N, I N T R, P C R E D)$ & 0.3843 & 0.5411 \\
\hline RGDPagric $=f($ TOEXP, INFL $A T I O N$, INTR, PCRED $)$ & 0.2041 & 0.3501 \\
\hline$R G D P \operatorname{man}=f(T O E X P, I N F L A T I O N, I N T R, P C R E D)$ & 0.1095 & 0.2956 \\
\hline$R G D P^{*}=(R E P E X, C A P E X, I N F L A T I O N, I N T R, P C R E D)$ & 0.2757 & 0.4296 \\
\hline
\end{tabular}

Appendix $2 \mathrm{~A}$ to $2 \mathrm{D}$ indicate the tests of structural stability of the estimated short-run models. The critical values fall within the upper and lower bounds of the graphs, thus suggesting that all estimated short-run models in the study are structurally stable.

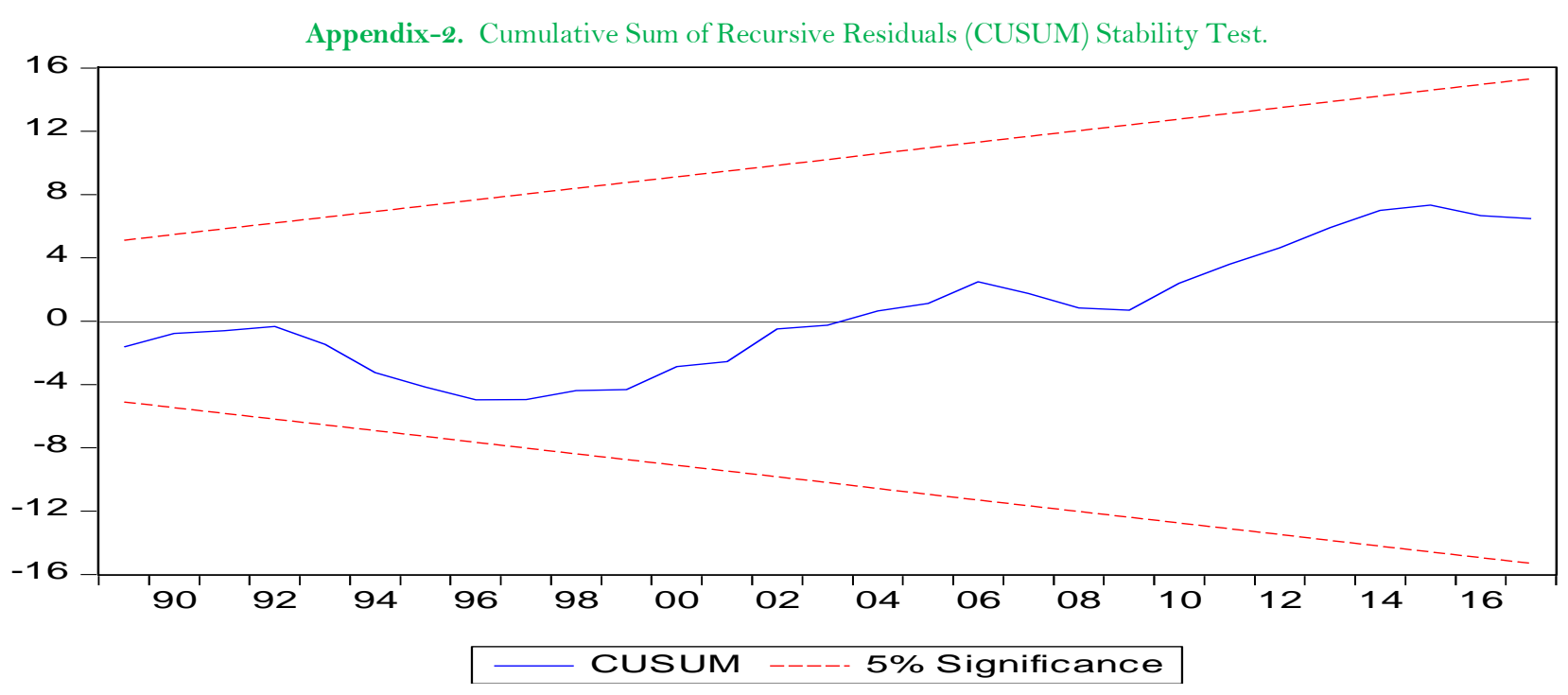

A: RGDP (with Total Government Expenditure) Model Cumulative Sum of Recursive Residuals
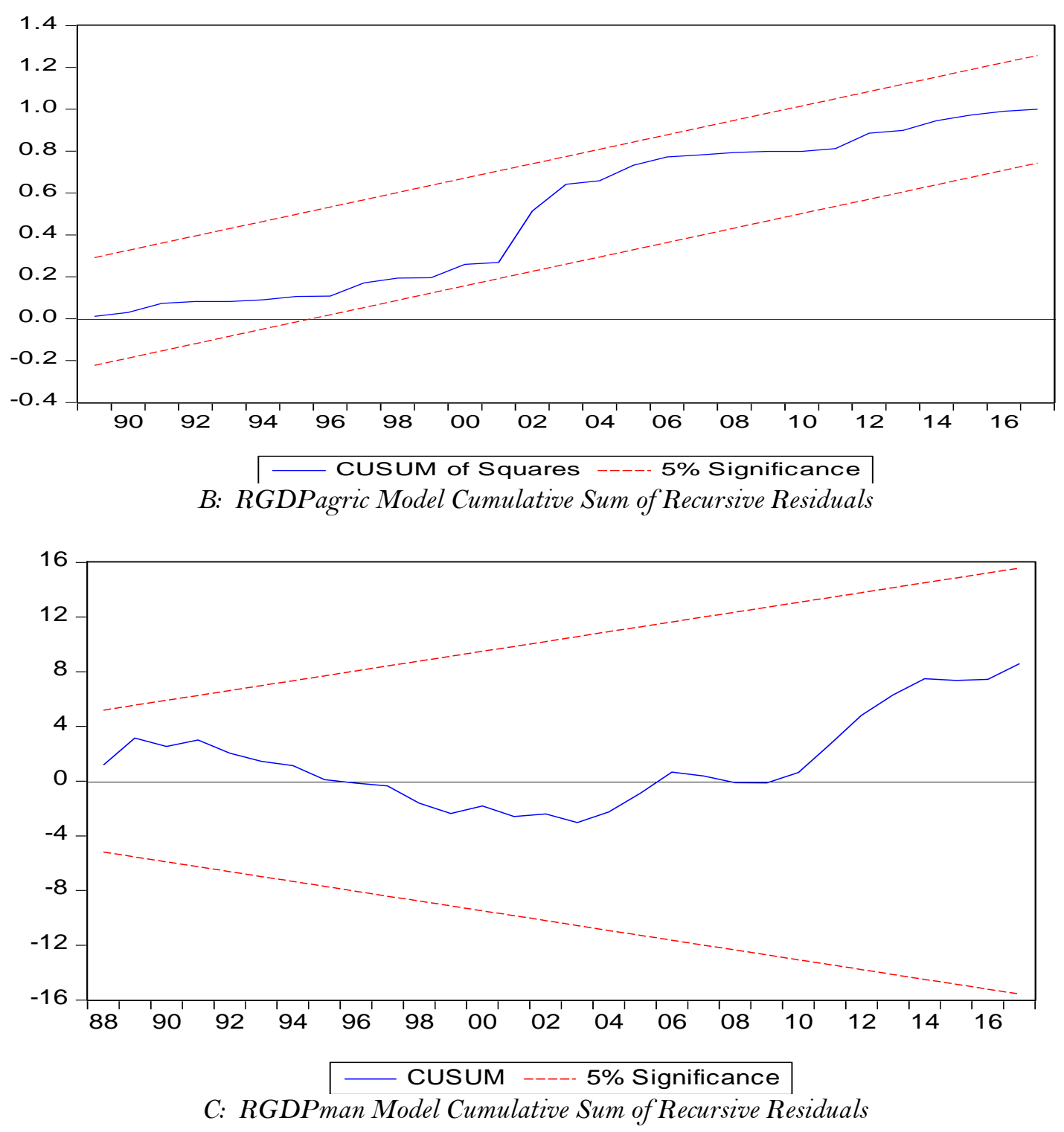
Asian Journal of Economics and Empirical Research, 2020, 7(1):64-73

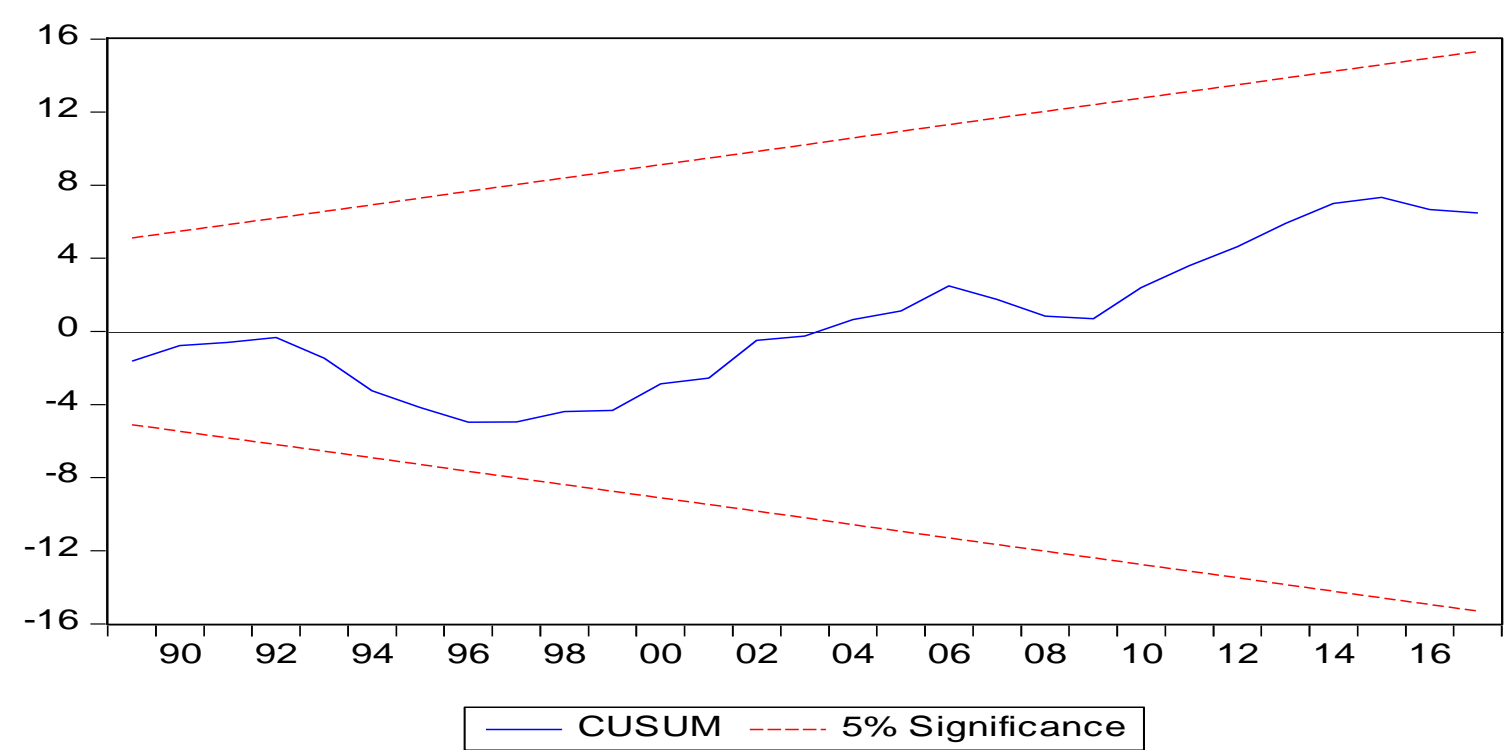

D: RGDP (with Current and Recurrent Expenditure) Model Cumulative Sum of Recursive Residuals 